\title{
How is patient-centred care conceptualized in women's health: a scoping review
}

\author{
Anna R. Gagliardi ${ }^{*}$ (D, Bryanna B. Nyhof ${ }^{2}$, Sheila Dunn ${ }^{3}$, Sherry L. Grace ${ }^{4}$, Courtney Green ${ }^{5}$, Donna E. Stewart ${ }^{2}$ and \\ Frances C. Wright ${ }^{6}$
}

\begin{abstract}
Background: Gendered disparities in health care delivery and outcomes are an international problem. Patientcentred care (PCC) improves patient and health system outcomes, and is widely advocated to reduce inequities. The purpose of this study was to review published research for frameworks of patient-centred care for women (PCCW) that could serve as the basis for quality improvement.
\end{abstract}

Methods: A scoping review was conducted by searching MEDLINE, EMBASE, CINAHL, SCOPUS, Cochrane Library, and Joanna Briggs index for English-language quantitative or qualitative studies published from 2008 to 2018 that included at least 50\% women aged 18 years or greater and employed or generated a PCCW framework. Findings were analyzed using a 6-domain PCC framework, and reported using summary statistics and narrative descriptions.

Results: A total of 9267 studies were identified, 6670 were unique, 6610 titles were excluded upon title/abstract screening, and 11 were deemed eligible from among 60 full-text articles reviewed. None were based on or generated a PCCW framework, included solely women, or analyzed or reported findings by gender. All studies explored or described PCC components through qualitative research or surveys. None of the studies addressed all 6 domains of an established PCC framework; however, additional PCC elements emerged in 9 of 11 studies including timely responses, flexible scheduling, and humanized management, meaning tailoring communication and treatment to individual needs and preferences. There were no differences in PCC domains between studies comprised primarily of women and other studies.

Conclusions: Given the paucity of research on PCCW, primary research is needed to generate knowledge about PCCW processes, facilitators, challenges, interventions and impacts, which may give rise to a PCCW framework that could be used to plan, deliver, evaluate and improve PCCW.

Keywords: Women's health, Patient-centred care, Equity, Quality, Frameworks, Models, Scoping review

\section{Background}

Inequities in access to and quality of health care are pervasive, leading to disparities in health outcomes. While there are multiple causal factors, one of the key issues is gender bias [1].

For example, research on access to care for cardiovascular disease revealed that women were far less likely to be referred for diagnostic tests and to cardiac rehabilitation compared with men [2], and even when referred, they were less likely to receive recommended treatment

\footnotetext{
*Correspondence: anna.gagliardi@uhnresearch.ca

'Toronto General Hospital Research Institute, University Health Network, 200

Elizabeth Street, 13 EN-228, Toronto, ON M5G2C4, Canada

Full list of author information is available at the end of the article
}

compared with men [3]. Similarly, another study of patients with acute myocardial infarction revealed that women received guideline-recommended interventions such as timely reperfusion, antiplatelet therapy, statins, and cardiac rehabilitation less often than men [4]. Such disparities in the quality of care for women may be heightened by race or ethnicity in both high- and lowresource countries, and by a lack of primary research including women participants $[5,6]$.

In 1995, the Fourth World Conference on Women of the United Nations highlighted the need to deliver health care services that are sensitive to the needs and preferences of women [2], and in 2009 the World Health Organization report, Women and Health, emphasized

(c) The Author(s). 2019 Open Access This article is distributed under the terms of the Creative Commons Attribution 4.0 International License (http://creativecommons.org/licenses/by/4.0/), which permits unrestricted use, distribution, and 
the need to improve the quality of women's health care services [7]. Over time, the concept of women's health has broadened from a focus on sexual and reproductive health to a life-course approach that considers other health challenges that affect women during and beyond their reproductive years, and the impact of social determinants on women's health, morbidity and mortality [8]. As a result of ongoing gender bias that influences women's health care and outcomes, one of the 17 goals in the United Nations report, Gender Equality in the 2030 Agenda for Sustainable Development, is to promote women's health and well-being by ensuring that women have universal access to comprehensive health care that is responsive to gender and the life course [9].

Patient-centred care (PCC) is an approach that tailors care to individual needs, preferences and circumstances by informing, engaging, and empowering patients (including families or care partners) [10]. PCC is considered a key element of high quality health care because it has been associated with patient (knowledge, relationship with providers, service experience and satisfaction, treatment compliance, health outcomes) and health system (cost-effective service delivery) outcomes [11-13]. Accumulating research offers insight on the dimensions of PCC, but reveals discrepancies in what is thought to constitute PCC. A scoping review of 19 studies published from 1994 to 2011 identified 25 unique frameworks or models of PCC; common domains pertained to the patient-provider relationship (sharing information, empathy, empowerment), partnership (sensitivity to needs, relationship-building), and health promotion (collaboration, case management, resource use) [14]. A systematic review of 26 studies published from 1992 to 2008 identified 13 unique instruments to assess PCC, further underscoring variability in how PCC is conceptualized [15].

Unfortunately many patients do not receive PCC, particularly those with limited education, poor health, or whose culture differs from their health care provider. A national survey in the United States showed that, among 2718 responding adults aged 40 years or greater with 10 common medical conditions, there was considerable variation in whether patients were told they had a choice of treatment and whether they were asked for input in the decision [16]. In a study of 509 adult patients seen by family physicians or general internists, PCC was observed more in for healthier, more educated patients [17]. A survey of 80 providers and 27 Muslim women found that both groups identified similar barriers to PCC: providers lacked understanding of patients' religious and cultural beliefs, and needs for modesty, and patients lacked understanding of disease processes and mistrusted the health care system [18].
Delivering patient-centred care for women (PCCW) may serve as an important means of reducing gendered disparities. However, it is unclear whether existing PCC frameworks or models are relevant to women's health, or if the components, delivery and experience of PCCW varies among women with different health conditions or personal characteristics. Greater understanding is needed of what constitutes PCCW to support systemlevel planning of services for women, and to inform the development of interventions targeted to women and their care providers that support PCCW. While others have reviewed published research on frameworks or models of PCC [14], no one has synthesized knowledge about PCCW frameworks or models. The purpose of this study was to review published research, and identify and compare existing PCCW frameworks or models. If PCCW frameworks or models are available, they could serve as the basis for evaluating and improving care delivery and outcomes among women. If lacking, then primary research is needed to explore the elements of PCC valued by women to inform the development of a comprehensive PCCW framework.

\section{Methods \\ Approach}

For this study, a scoping review was chosen as the methodologic approach. A scoping review aims to rapidly map the key concepts in published research on a given topic [19]. Unlike a systematic review, which aims to provide answers to a well-defined research question, a scoping review addresses broader topics, includes research of various designs, describes the extent, range and nature of research, and identifies gaps in the existing literature [20]. A scoping review consists of five steps: scoping, searching, screening, data extraction, and data analysis. Reporting of the methods and findings was guided by the Preferred Reporting Items for Systematic Reviews and Meta-Analysis (PRISMA) criteria [21]. Data for this review were publicly available so institutional review board approval was not necessary. A protocol was not registered for this review.

\section{Scoping}

To become familiar with this topic, a quick scan of relevant literature was undertaken by searching MEDLINE using the Medical Subject Headings: women's health and patient-centered care. The titles and abstracts of the initial search results were screened by KB and ARG, and discussed by the research team to collectively establish eligibility criteria based on the Population, Issue, Comparisons, Outcomes (PICO) framework, which then informed the comprehensive search strategy. Given the preliminary nature of a scoping review, the research team decided to focus on general PCCW frameworks 
pertaining to women with any health care concern or condition, and to investigate disease-specific PCCW frameworks in a separate review (reported separately).

Population referred to women, family members or care partners aged 18 years or greater with any health care concern or condition, or clinicians (i.e. physicians, nurses) involved in the care of those women in any type of health care setting. Issues referred to the identification or development of PCCW frameworks in which PCC was explicitly labelled in the published manuscript as patient-, person-, woman-, women-, client- or familycentered/centred care. Although there is no standardized definition of PCC, PCC can be thought of as the individualized, timely, coordinated, respectful, and compassionate care of patients that engages women and takes into consideration their values, preferences, information and supportive care needs, such that they have the ability to make clinical decisions and manage their own health [10]. With respect to comparisons, qualitative (interviews, focus groups, qualitative case studies), quantitative (questionnaires, randomized controlled trials, time series, before/after studies, prospective or retrospective cohort studies, case control studies) or mixed methods studies were eligible if they explored and/or compared patient or clinician views about PCCW, experiences with PCCW including enablers or barriers, or suggestions for improving PCCW, or evaluated the impact of strategies implemented to support or improve PCCW. Such studies could evaluate PCCW in patients and/or clinicians with and without exposure to interventions, before and after exposure, or across different interventions. The primary outcome of interest was a PCCW framework (or model, theory, etc.), either employed by study, or compiled or developed by the study based on data collected in any of the aforementioned ways that may have included one or more of, but was not limited to PCCW constructs, processes, determinants (enablers, barriers), or outcomes.

Studies were considered ineligible if they primarily involved trainees (i.e. medical students or residents) or allied health care professionals (i.e. dentists, physiotherapists); concluded that PCC is needed without having studied PCC; labelled any form of clinical care or multi-/inter-disciplinary care for patients as PCC; investigated patient engagement in organizational- or systemlevel health service planning; examined the illness experience of patients rather than the care experience; focused on care delivered by peers or lay persons; or studied the patient-centered medical home, healthrelated quality of life, electronic applications for patients, or patient preferences for treatment or clinical outcomes. Publications in the form of protocols, editorials, commentaries, letters, or meeting abstracts or proceedings were excluded. Systematic reviews were also excluded although references were searched for eligible primary studies.

\section{Searching}

A comprehensive literature search was conducted on February 26, 2018 in MEDLINE, EMBASE, SCOPUS and CINAHL by ARG based on a search strategy that was devised by a medical librarian and complied with the Peer Review of Electronic Search Strategies checklist (Additional File 1) [22]. The search was purposefully broad, including concepts for women's health combined with explicit mention of PCC-related terms; by choosing to screen a large number of search results, we hoped to capture studies that generated frameworks that might otherwise be missed. The search was limited to research published in English language from 2008 to that date, a 10-year time span during which research on PCC became prevalent. We chose not to search the grey literature given the methodological challenges that have been identified by others such as sensitivity versus specificity, replicability, risk of bias, and intensity of time and effort $[23,24]$. Search results were exported into Excel, in which screening and data extraction were performed.

\section{Screening}

As a pilot test, KB, HL and ARG independently screened 50 records, and then compared and discussed findings to establish a shared understanding of how to interpret and apply eligibility criteria. Then titles and abstracts were screened independently by KB and HL. All articles considered potentially eligible by at least one reviewer were retrieved for full-text screening, which was undertaken concurrent with data extraction. During screening it became apparent that few studies focused on women only, so it was decided to include studies if at least half of the participants were women or outcomes were analyzed by gender.

\section{Data extraction}

A data extraction table was developed to collect information on author, publication year, country, research design (including methods of data collection, number of participants, age range, proportion of female participants), study objective, term used to refer to PCC, definition or description of PCC employed or generated, and related findings. HL extracted data, which were independently checked by ARG.

\section{Data analysis}

Summary statistics were used to report the number of studies published per year, country, research design, and term used for PCC. Definitions or descriptions of PCCW across all studies were reported textually. To further analyze and compare PCCW across studies, PCC 
elements employed or generated in each study were mapped to the McCormack et al. PCC framework, and the number of domains addressed in each study was summarized [25]. The McCormack et al. framework was chosen from among other PCC frameworks we identified in the literature because it was rigorously developed, extends beyond the clinical encounter, and is more comprehensive than other frameworks [14]. It was established by systematically reviewing literature and relevant theories, observing 38 medical encounters between cancer patients and oncologists, interviewing those 38 patients, and then reviewing the proposed domains with a 13-member expert panel to refine the framework. The resulting PCC framework consists of 31 sub-domains within six domains: fostering clinician-patient relationships, exchanging information, recognizing and responding to patient emotions, managing uncertainty, making decisions, and enabling patient self-management.

\section{Results}

Search results

A total of 9267 studies were identified, of which 6670 were unique, and 6610 titles were excluded, leaving 60 full-text articles to be screened. Of these, 48 articles were excluded: 28 did not study PCCW, 13 were not an eligible publication type, and 8 did not report the number of women participants or less than half were women. A total of 11 studies were eligible for review (Fig. 1). Data extracted from these studies are shown in Table 1.

\section{Study characteristics}

Studies were published from 2008 to 2017 inclusive in both higher- and lower-resource countries with differing health care systems including the United States $(n=3)$, Australia $(n=2)$ and one each in Canada, Hungary, Iran, Mexico, Netherlands and Scotland. PCC was studied for critical and intensive care, chronic conditions, older people, ear, nose and throat care, primary care, surgical inpatients, and complementary and alternative medicine. In terms of research design, the majority of studies employed qualitative interviews or focus groups (8, $72.7 \%)$, while 3 studies involved surveys (27.2\%). The majority of studies used the term patient-centered or -centred or -centeredness (10, 90.9\%). No studies included solely women, and no studies analyzed or reported findings by gender. At least $80.0 \%$ of participants were women in 4 of the 11 studies [31, 34-36].

\section{PCCW framework}

None of the 11 studies was based upon, or generated a framework, model, theory or approach specific to PCCW. Instead they sought to identify and describe the components of PCC.

\section{PCC definition or measurement}

Of the 11 included studies, 3 (27.3\%) did not a priori define PCC. Among the 8 (72.7\%) studies that defined PCC, 2 (25.0\%) studies referred to it as accommodating user views in the design or evaluation of health services (system level), and $6(75.0 \%)$ studies referred to it as valuing people as individuals, respecting their needs and values, and addressing those preferences in clinical decisions (patient level). One study asked patients what PCC meant to them and despite being unfamiliar with the word patient-centred, they were able to articulate that it meant they were involved in their care, attended to, and connected with their clinician [34]. All 11 studies described how PCC was measured; among the qualitative studies, participants were asked about their experiences of care and what they valued about their clinician, environment and information received. Quantitative studies asked participants about attributes of PCC including respect for patient values, engagement, quality of communication and relationship with care providers.

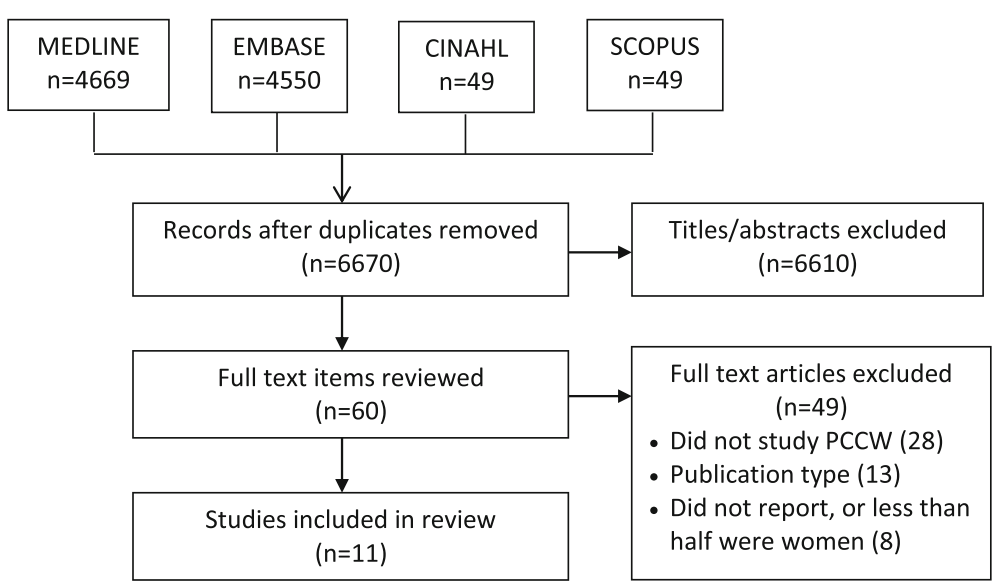

Figure 1 PRISMA diagram 
Table 1 Data extracted from included studies

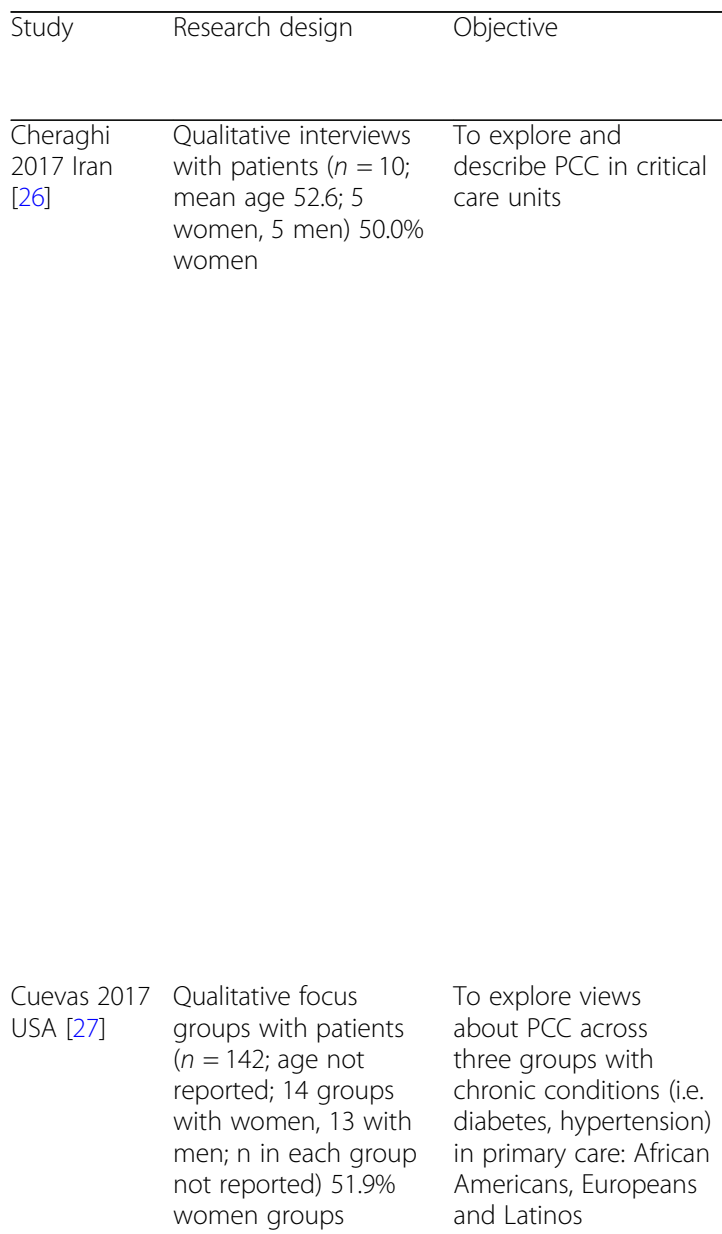

$\begin{array}{lll}\text { PCC } & \text { PCC definition or } & \text { McCormack PCC } \\ \text { label } & \text { measure } & \text { elements described or } \\ & \text { recommended }\end{array}$

patient- Authors defined PCC as • Relationship:

Maintaining human

$\begin{array}{ll}\text { respectful care in } & \text { dignity, fulfilling } \\ \text { response to patients' } & \text { patients' needs }\end{array}$

preferences, needs and - Information:

values During

interviews, participants

were asked to describe

experiences and

perceptions of PCC and

how it can be

achieved; themes

established inductively

Establishing

therapeutic

communication

analyzing the

situation,

individualizing care;

patients receiving

adequate information

about treatment

reduced anxiety

- Decision-making: In-

volving patients in

decision-making in-

creased satisfaction

with care

- Self-management: Cli-

nicians addressed and

alleviated concerns,

and outlined self-care

activities, which pro-

moted patient

autonomy

- Information: Patients want clinician

patient- PCC not defined

centered During interviews, participants were asked about what makes a good and bad experience; themes established inductively

and Latinos

attentive to patients' needs and listen to their comments/ concerns

- Decision-making: Patients wanted to be
Adamson

2016

Scotland

[28]
Qualitative interviews with patients $(n=15$, aged 69 to $95 ; 8$ women, 7 men) 53.3\% women
To understand the meaning of PCC for older people attending day hospitals for a variety of health care issues more participatory in their interactions with providers and be more involved in their own care

person- PCC not defined

centred During interviews, participants were asked about talking with nurses, relationships, involvement in decisions, feeling valued, and getting information; themes emerged inductively
- Relationships: Developed trusting relationship with nursing staff, depended on nurses and had confidence that they would advocate for them, were informed about their progress with treatment or care, built rapport with staff

- Information: patients appreciated when they were informed
Additional PCC elements described or recommended

- Ease of contact

Timely response to requests gained patient trust and sense of security

- Humanization: identify, prioritize, and fulfill patients biological, psychosocial, and spiritual needs), individualization of care

- Consider race/ ethnicity: African Americans felt that it was important for clinician to consider patient's race in treatment plans - Speak native language: Many preferred a physician that knew their language in order to communicate effectively with patients, enable patients to understand their recommendations

* differences in findings between men and women not reported

- Coordination of care: Patients reported that they were seen by clinicians in their home following treatment to see if they had everything they needed. This continuation of care was appreciated 
Table 1 Data extracted from included studies (Continued)

Research design

Objective

Gill 2016

Qualitative interviews Canada [29] with patients and family members ( $n=$ 32; $15 / 46.9 \%$ aged 50 to 64,8 were $<50,9 \geq$ 65; 11 patients, 21 family; 17 women, 15 men) $53.1 \%$ women
To understand views about PCC among intensive care unit patients and their families patient- PCC not defined

centered During interviews participants were asked to describe experiences they wished had been different; themes emerged inductively

progressing with

treatment. Following

treatment, patients

valued knowing what was coming next in

care.

- Relationships: when staff shared aspects of their own life with the patient and participated in casual 'banter' this strengthened the relationship with clinical staff

- Decision-making: Patients felt involved in decision-making, which enhanced their dignity and respect

- Decision-making: Family felt stressed about being patient's spokesperson. Families' ability to make decisions about patient care and have confidence in their decisions was impacted by the information and support they received.

- Relationship: Providers were perceived as impatient and family members sometimes felt dismissed; they desired greater empathy

Doubova Telephone survey of To explore public 2016 Mexico patients $(n=6005$; [30] 59; 3126 women, 2869 contribute to high men) $52.1 \%$ women views about the PCC quality primary care patient- PCC takes into account centered the view of users in the design, provision and evaluation of health care services Survey included 10 PCC attributes based on Commonwealth Fund survey used in other countries: primary care provider (PCP) knows relevant information about the patient's medical history; PCP gives an opportunity to ask questions about recommended treatment; PCP spends enough time with the patient; PCP explains things in a way that is easy to understand; PCP helps the patient to coordinate or arrange his/her
- Information: PCP provides information and explanations, and opportunities to ask questions
- Ease of contact: Easy to reach the primary care clinic

- Problems are solved: PCP solves most health problems

- Familiarity with patient: PCP knows relevant info about patient's medical history

- Coordination of care: PCP coordinates healthcare 
Table 1 Data extracted from included studies (Continued)

\begin{tabular}{|c|c|c|c|c|c|c|}
\hline$\overline{\text { Study }}$ & Research design & Objective & $\begin{array}{l}\text { PCC } \\
\text { label }\end{array}$ & $\begin{array}{l}\text { PCC definition or } \\
\text { measure }\end{array}$ & $\begin{array}{l}\text { McCormack PCC } \\
\text { elements described or } \\
\text { recommended }\end{array}$ & $\begin{array}{l}\text { Additional PCC } \\
\text { elements described or } \\
\text { recommended }\end{array}$ \\
\hline & & & & $\begin{array}{l}\text { healthcare from other } \\
\text { doctors and places; } \\
\text { patient perceives } \\
\text { difficulties in } \\
\text { communication with } \\
\text { the primary care clinic } \\
\text { during regular practice } \\
\text { hours about a health } \\
\text { problem; a nurse or } \\
\text { another clinical staff } \\
\text { (other than a doctor) is } \\
\text { involved in primary } \\
\text { healthcare; PCP who } \\
\text { during a routine } \\
\text { medical checkup in the } \\
\text { past } 2 \text { years talked } \\
\text { about an exercise or } \\
\text { physical activity; PCP } \\
\text { who during a routine } \\
\text { medical checkup in the } \\
\text { past } 2 \text { years spoke of a } \\
\text { healthy diet and } \\
\text { healthy eating; PCP } \\
\text { who during a routine } \\
\text { medical checkup in the } \\
\text { past } 2 \text { years talked } \\
\text { about things that } \\
\text { worry the patient or } \\
\text { cause stress }\end{array}$ & & \\
\hline $\begin{array}{l}\text { Raja } 2015 \\
\text { USA [31] }\end{array}$ & $\begin{array}{l}\text { Qualitative interviews } \\
\text { with patients }(n=20 \text {; } \\
\text { aged } 21 \text { to } 74 ; 18 \\
\text { women, } 2 \text { men) } 90.0 \% \\
\text { women }\end{array}$ & $\begin{array}{l}\text { To explore views } \\
\text { about PCC among } \\
\text { primary care patients } \\
\text { with little or no health } \\
\text { insurance }\end{array}$ & $\begin{array}{l}\text { patient- } \\
\text { centered }\end{array}$ & $\begin{array}{l}\text { Authors cited Institute } \\
\text { of Medicine PCC } \\
\text { definition: Providing } \\
\text { care that is respectful } \\
\text { and responsive to } \\
\text { individual patient } \\
\text { preferences, needs, and } \\
\text { values, and ensuring } \\
\text { that patient values } \\
\text { guide all clinical } \\
\text { decisions During } \\
\text { interviews, participants } \\
\text { were asked about what } \\
\text { made visits positive or } \\
\text { negative; themes } \\
\text { emerged inductively }\end{array}$ & $\begin{array}{l}\text { - Relationship: Chatting } \\
\text { with patients, asking } \\
\text { questions, and telling } \\
\text { patients about } \\
\text { themselves helps } \\
\text { build rapport } \\
\text { - Information: Give } \\
\text { overview of the } \\
\text { procedure and clear } \\
\text { expectations, results, } \\
\text { appointment flow, } \\
\text { realistic expectation } \\
\text { of pain; patients } \\
\text { desired more time } \\
\text { with provider }\end{array}$ & $\begin{array}{l}\text { - Physical setting: } \\
\text { Pleasant environment } \\
\text { makes participants } \\
\text { feel respected and } \\
\text { welcomed } \\
\text { - Humanization: } \\
\text { Feeling listened to, } \\
\text { cared for, or seen as } \\
\text { an entire human } \\
\text { being with needs } \\
\text { and emotions; } \\
\text { providers consider } \\
\text { the totality of a } \\
\text { patient's physical } \\
\text { health, their ways of } \\
\text { coping, and their } \\
\text { environment } \\
\text { - Avoiding jargon: } \\
\text { Express technical } \\
\text { terms in an } \\
\text { understandable } \\
\text { manner } \\
\text { - Ease of contact: } \\
\text { Inability to schedule } \\
\text { appointments led to } \\
\text { feeling devalued }\end{array}$ \\
\hline $\begin{array}{l}\text { Leijen- } \\
\text { Zeelenberg } \\
2015 \\
\text { Netherlands } \\
\text { [32] }\end{array}$ & $\begin{array}{l}\text { Qualitative interviews } \\
\text { with patients ( } n=22 \text {; } \\
\text { mean age } 52.8 \text { years; } \\
13 \text { women, } 9 \text { men) } \\
59.1 \% \text { women }\end{array}$ & $\begin{array}{l}\text { To explore PCC views } \\
\text { and preferences } \\
\text { among those visiting } \\
\text { an ear, nose \& throat } \\
\text { outpatient unit }\end{array}$ & $\begin{array}{l}\text { patient- } \\
\text { centred }\end{array}$ & $\begin{array}{l}\text { Authors defined PCC } \\
\text { using Institute of } \\
\text { Medicine (IOM) } 6 \\
\text { domains: Respect for } \\
\text { patients' values, } \\
\text { preferences and } \\
\text { expressed needs; } \\
\text { Information, } \\
\text { communication and } \\
\text { education; }\end{array}$ & $\begin{array}{l}\text { - Information: Some } \\
\text { respondents felt that } \\
\text { they had to be } \\
\text { assertive at the clinic } \\
\text { in order to get } \\
\text { respect for their } \\
\text { preferences and } \\
\text { needs. Being able to } \\
\text { ask questions during } \\
\text { consultations and }\end{array}$ & $\begin{array}{l}\text { - Coordination of care: } \\
\text { some find it difficult } \\
\text { to plan more than } 3 \\
\text { months in advance } \\
\text { and disliked the } \\
\text { inflexibility in the } \\
\text { planning system. } \\
\text { Negative experiences } \\
\text { due to alternating } \\
\text { doctors (seeing }\end{array}$ \\
\hline
\end{tabular}


Table 1 Data extracted from included studies (Continued)

\begin{tabular}{|c|c|c|c|c|c|c|}
\hline Study & Research design & Objective & $\begin{array}{l}\text { PCC } \\
\text { label }\end{array}$ & $\begin{array}{l}\text { PCC definition or } \\
\text { measure }\end{array}$ & $\begin{array}{l}\text { McCormack PCC } \\
\text { elements described or } \\
\text { recommended }\end{array}$ & $\begin{array}{l}\text { Additional PCC } \\
\text { elements described or } \\
\text { recommended }\end{array}$ \\
\hline & & & & $\begin{array}{l}\text { Coordination and } \\
\text { integration of care; } \\
\text { Emotional support - } \\
\text { relieving fear and } \\
\text { anxiety; Physical } \\
\text { comfort; Involvement } \\
\text { of family and friends } \\
\text { During interviews, } \\
\text { participants were asked } \\
\text { to share experiences } \\
\text { related to each of the } \\
6 \text { IOM domains; views } \\
\text { about themes emerged } \\
\text { inductively }\end{array}$ & $\begin{array}{l}\text { receive clear } \\
\text { responses was very } \\
\text { important. It is also } \\
\text { important to get an } \\
\text { explanation when an } \\
\text { expressed preference } \\
\text { is not being complied } \\
\text { with. } \\
\text { - Emotional support: } \\
\text { More attention } \\
\text { needed on emotional } \\
\text { and psychological } \\
\text { support. }\end{array}$ & $\begin{array}{l}\text { different doctors at } \\
\text { subsequent } \\
\text { appointments). } \\
\text { - Physical setting: Nice } \\
\text { atmosphere at } \\
\text { outpatient clinic } \\
\text { helps provide } \\
\text { physical comfort. } \\
\text { - Involvement of family } \\
\text { and friends }\end{array}$ \\
\hline $\begin{array}{l}\text { Papp } 2014 \\
\text { Hungary } \\
{[33]}\end{array}$ & $\begin{array}{l}\text { Qualitative focus } \\
\text { groups }(n=61 ; 14 \\
\text { groups with } 8 \text { to } 10 \\
\text { per group; } 69.8 \% \text { aged } \\
41 \text { or greater; } 34 \\
\text { women, } 27 \text { men) } \\
55.7 \% \text { women }\end{array}$ & $\begin{array}{l}\text { To explore views } \\
\text { about the elements of } \\
\text { high quality primary } \\
\text { care including patient- } \\
\text { centeredness }\end{array}$ & $\begin{array}{l}\text { patient- } \\
\text { centered }\end{array}$ & $\begin{array}{l}\text { Authors defined PCC as } \\
\text { the degree to which a } \\
\text { system actually } \\
\text { functions by placing } \\
\text { the patient at the } \\
\text { center of its delivery of } \\
\text { health-care, assessed in } \\
\text { terms of patient's ex- } \\
\text { perience During inter- } \\
\text { views, participants }\end{array}$ & $\begin{array}{l}\text { - Information: Nurses } \\
\text { should have an } \\
\text { important role in } \\
\text { providing information } \\
\text { to patients; physicians } \\
\text { should spend time to } \\
\text { explain the situation } \\
\text { to patients } \\
\text { - Relationship: Patients } \\
\text { expect doctor to be }\end{array}$ & $\begin{array}{l}\text { - Avoiding jargon: } \\
\text { Information for } \\
\text { patients should be } \\
\text { understandable and } \\
\text { clear } \\
\text { - Humanization: } \\
\text { Patients expect to be } \\
\text { treated as a human } \\
\text { being, not only as a } \\
\text { disease }\end{array}$ \\
\hline
\end{tabular}
were asked about gen- empathetic, friendly, eral aspects of quality attentive, good and elements of listeners, sympathetic, patient-centeredness; and willing to help

Marshall

2012

Australia
Qualitative interviews with patients $(n=10$; aged 30 to late 60 's; 8 women, 2 men) $80.0 \%$ women
To explore views about PCC among surgical inpatients
Bann 2010 Survey of patients USA [35]

\footnotetext{
$(n=216 ; 43 \%$ aged 55

or greater; 184

women, 31 men)
}

$85.2 \%$ women
To assess views about PCC among complementary and alternative medicine patients themes emerged inductively

patient- Authors note centred inconsistency in PCC definitions (treating people as individuals, tailoring care to patients' needs, understanding the patient as a unique human being, etc.) and lack of definition derived from patients During interviews, participants were asked what they valued in care, what they thought patientcentred care meant, and what constitutes patient-centred care themes emerged inductively

patient- Authors defined PCC as centered building an empathetic relationship that considers the patient as a partner with the health care provider in the priorities, problems, and goals of

Treatment. The survey included 10 PCC attributes: I feel seen and heard as a unique individual by my therapist; My therapist
- Relationship: Helpful, respectful, open communication

- Decision-making: Being involved in decisions and to contribute in care consultations

\author{
- Humanization: \\ Feeling seen and \\ heard as a unique \\ individual; receiving \\ individualized \\ treatment \\ - Problems are solved: \\ The therapist being \\ interested in finding \\ and addressing their \\ health problems
}


Table 1 Data extracted from included studies (Continued)

\begin{tabular}{|c|c|c|c|c|c|c|}
\hline Study & Research design & Objective & $\begin{array}{l}\text { PCC } \\
\text { label }\end{array}$ & $\begin{array}{l}\text { PCC definition or } \\
\text { measure }\end{array}$ & $\begin{array}{l}\text { McCormack PCC } \\
\text { elements described or } \\
\text { recommended }\end{array}$ & $\begin{array}{l}\text { Additional PCC } \\
\text { elements described or } \\
\text { recommended }\end{array}$ \\
\hline & & & & $\begin{array}{l}\text { has a full picture of me } \\
\text { as a unique individual; } \\
\text { My therapist is really } \\
\text { interested in finding } \\
\text { and addressing my } \\
\text { health problems; The } \\
\text { root causes of my } \\
\text { problems are identified } \\
\text { by my therapist; The } \\
\text { root causes of my } \\
\text { problems are being } \\
\text { treated by my } \\
\text { therapist; The } \\
\text { treatment is } \\
\text { individualized for me at } \\
\text { each session; My } \\
\text { therapist receives } \\
\text { feedback from my } \\
\text { body that guides } \\
\text { treatment; My therapist } \\
\text { asks me for feedback } \\
\text { from my body that } \\
\text { guides treatment; I } \\
\text { know what to expect } \\
\text { during treatment } \\
\text { sessions; My therapist } \\
\text { teaches me ways to } \\
\text { relieve symptoms } \\
\text { myself }\end{array}$ & & \\
\hline $\begin{array}{l}\text { Davis } 2008 \\
\text { Australia } \\
\text { [36] }\end{array}$ & $\begin{array}{l}\text { Survey of patients } \\
(n=78 ; \text { mean age } 82 \\
\text { years; } 72 \text { women, } 6 \\
\text { men) } 92.3 \% \text { women }\end{array}$ & $\begin{array}{l}\text { To assess views about } \\
\text { PCC among older } \\
\text { patients recently } \\
\text { discharged from a sub- } \\
\text { acute setting }\end{array}$ & $\begin{array}{l}\text { person- } \\
\text { centred }\end{array}$ & $\begin{array}{l}\text { Authors defined PCC as } \\
\text { valuing people as } \\
\text { individuals and as the } \\
\text { person being the focal } \\
\text { point in a partnership } \\
\text { that is both respectful } \\
\text { and reciprocal The } \\
\text { survey included five } \\
\text { dimensions: } \\
\text { personalisation, } \\
\text { empowerment, } \\
\text { information, } \\
\text { approachability and } \\
\text { availability, and respect }\end{array}$ & $\begin{array}{l}\text { - Information: Many felt } \\
\text { that they were not } \\
\text { being told what was } \\
\text { going on, lack of } \\
\text { communication } \\
\text { between staff } \\
\text { - Relationship: Respect } \\
\text { was typically } \\
\text { demonstrated by staff. }\end{array}$ & $\begin{array}{l}\text { - Humanization: } \\
\text { Treated as a whole } \\
\text { person } \\
\text { - Ease of contact: } \\
\text { Majority found they } \\
\text { were unable to locate } \\
\text { nurses for assistance, } \\
\text { and would like to } \\
\text { speak with nurses } \\
\text { and doctors more } \\
\text { often }\end{array}$ \\
\hline
\end{tabular}

\section{PCC domains}

Table 2 summarizes the mapping of PCC concepts in included studies to McCormack's PCC framework [25]. None of the studies addressed all 6 domains. Although one study addressed 4 of 6 domains and two studies addressed 3 of 6 domains. The domains most frequently addressed by the 11 studies were exchanging information $(n=8)$, fostering a patient-clinician relationship $(n=7)$ and making decisions $(n=5)$. With respect to exchanging information, patients wanted clinicians to ask about their life circumstances and personal values, listen and acknowledge needs or concerns, accommodate questions, detail next steps or follow-up care, provide information about treatment options, and justify treatment prescribed when counter to patient preference [26-28, 30-33, 36]. Regarding fostering a patient-clinician relationship, patients wanted clinicians to be respectful, advocate for them, get to know them, share information about themselves, engage family members, express empathy, not rush them, and allow them to maintain dignity [26, 28, 29, 31, 33, 34]. Regarding decision-making, patients wanted to be sufficiently informed such that they and family members could be involved in decisions, which they said enhance satisfaction, respect, dignity [26-29, 34]. Domains least addressed among the 11 studies were responding to patient emotions $(n=1)$, enabling patient self-management $(n=1)$ and managing uncertainty $(n=0)$. Patients said that clinicians should offer more attention to emotional and psychological needs [32], and they appreciated autonomy when clinicians outlined self-care activities [26]. There were no differences in PCC domains between studies comprised primarily of women [31, 34-36] and other studies. 
Table 2 PCC domains measured or revealed in included studies

\begin{tabular}{|c|c|c|c|c|c|c|c|}
\hline \multirow[t]{2}{*}{ Study } & $\begin{array}{l}\text { Fostering the } \\
\text { relationship }\end{array}$ & $\begin{array}{l}\text { Exchanging } \\
\text { information }\end{array}$ & $\begin{array}{l}\text { Addressing } \\
\text { emotions }\end{array}$ & Managing uncertainty & Making decisions & $\begin{array}{l}\text { Enabling self- } \\
\text { management }\end{array}$ & \multirow{2}{*}{$\begin{array}{l}\text { Domains } \\
\text { per study } \\
\text { (n) }\end{array}$} \\
\hline & $\begin{array}{l}\text { - Discuss } \\
\text { roles and } \\
\text { responsibilities } \\
\text { • Honesty } \\
\text { and openness } \\
\text { • Trust in } \\
\text { clinician } \\
\text { competence } \\
\text { • Express } \\
\text { caring } \\
\text { • Build } \\
\text { rapport }\end{array}$ & $\begin{array}{l}\text { - Explore needs } \\
\text { and } \\
\text { preferences } \\
\text { - Share } \\
\text { information } \\
\text { - Provide } \\
\text { information } \\
\text { resources } \\
\text { - Assess and } \\
\text { facilitate } \\
\text { understanding }\end{array}$ & $\begin{array}{l}\text { - Explore and } \\
\text { identify } \\
\text { emotions } \\
\text { - Assess anxiety } \\
\text { or depression } \\
\text { - Validate } \\
\text { emotions } \\
\text { - Express } \\
\text { empathy or } \\
\text { reassurance } \\
\text { - Provide help } \\
\text { to deal with } \\
\text { emotions }\end{array}$ & $\begin{array}{l}\text { - Define uncertainty } \\
\text { - Assess uncertainty } \\
\text { (cognitive) } \\
\text { - Use emotion-focused } \\
\text { management strategies } \\
\text { (affective) } \\
\text { - Use problem-focused } \\
\text { management strategies } \\
\text { (behavioural) }\end{array}$ & $\begin{array}{l}\text { - Communicate about } \\
\text { decision needs, } \\
\text { support and process } \\
\text { - Prepare for deliberation } \\
\text { and decision } \\
\text { - Make and implement a } \\
\text { choice and action plan } \\
\text { - Assess decision quality } \\
\text { and reflect on choice }\end{array}$ & $\begin{array}{l}\text { - Learn and } \\
\text { assess } \\
\text { - Share and } \\
\text { advise } \\
\text { - Prioritize } \\
\text { and plan } \\
\text { - Prepare, } \\
\text { implement } \\
\text { and assist } \\
\text { - Arrange } \\
\text { and follow- } \\
\text { up }\end{array}$ & \\
\hline $\begin{array}{l}\text { Cheraghi } 2017 \\
\text { Iran [26] }\end{array}$ & $x$ & $x$ & - & - & $x$ & $x$ & 4 \\
\hline $\begin{array}{l}\text { Cuevas } 2017 \\
\text { United States } \\
\text { [27] }\end{array}$ & - & $x$ & - & - & $x$ & - & 2 \\
\hline $\begin{array}{l}\text { Adamson } 2017 \\
\text { Scotland [28] }\end{array}$ & $x$ & $x$ & - & - & $x$ & - & 3 \\
\hline $\begin{array}{l}\text { Gill } 2016 \text { Canada } \\
\text { [29] }\end{array}$ & $x$ & - & - & - & $x$ & - & 2 \\
\hline $\begin{array}{l}\text { Doubova } 2016 \\
\text { Mexico [30] }\end{array}$ & - & $x$ & - & - & - & - & 1 \\
\hline $\begin{array}{l}\text { Raja } 2015 \text { United } \\
\text { States [31] }\end{array}$ & $x$ & $x$ & - & - & - & - & 2 \\
\hline $\begin{array}{l}\text { Leijen- } \\
\text { Zeelenberg } 2015 \\
\text { Netherlands [32] }\end{array}$ & - & $x$ & $x$ & - & - & - & 2 \\
\hline $\begin{array}{l}\text { Papp } 2014 \\
\text { Hungary [33] }\end{array}$ & $x$ & $x$ & $x$ & - & - & - & 3 \\
\hline $\begin{array}{l}\text { Marshall } 2012 \\
\text { Australia [34] }\end{array}$ & $x$ & - & - & - & $x$ & - & 2 \\
\hline $\begin{array}{l}\text { Bann } 2010 \\
\text { United States } \\
\text { [35] }\end{array}$ & - & - & - & - & - & - & 0 \\
\hline $\begin{array}{l}\text { Davis } 2008 \\
\text { Australia [36] }\end{array}$ & $x$ & $x$ & - & - & - & - & 2 \\
\hline $\begin{array}{l}\text { Studies including } \\
\text { domains ( } n, \% \text { of } \\
11)\end{array}$ & $7(63.6)$ & $9(72.7)$ & $2(18.2)$ & $0(0.0)$ & $5(45.5)$ & $1(9.1)$ & \\
\hline
\end{tabular}

\section{Additional PCC elements}

Although studies did not consistently address PCC domains according to the McCormack et al. framework, other elements relevant to PCC were addressed in nine (81.8\%) of 11 studies (Table 1$)$. For example, timely responses to patient requests helped to gain trust and security and continuation and coordination of care following treatment helped patients to feel cared for. Flexibility of scheduling allowed patients to plan their life around care and inflexibility of scheduling and limited appointment times led to patients feeling devalued. Several studies identified the theme of humanization, meaning feeling seen and heard as a person and receiving individualized communication and treatment that fits their personal needs. There were no differences in additional PCC elements between studies comprised primarily of women [31, 34-36] and other studies.

\section{Discussion}

PCCW may attenuate the widespread gendered disparities in health care delivery and outcomes. However, this review revealed that there are no established frameworks of PCCW. Studies varied in how they described PCC, with little direct consideration of women's unique needs and preferences because none of the studies included solely women, or analyzed or reported findings by gender. Moreover, none of the studies addressed all 6 domains of an established PCC framework, identifying 
specific gaps in how PCCW has been conceptualized or operationalized [25]. However, additional PCC elements emerged in 9 of 11 studies including timely responses, flexible scheduling, and humanized or individualized management.

These findings are novel because no prior work had conceptualized PCC specifically for women. While numerous frameworks for PCC are available, comparison of domains across those frameworks demonstrated variability $[14,15,25]$. Our study also showed that, while some PCC components in included studies matched those of the McCormack et al. framework [25], additional PCC elements emerged. Given that the McCormack et al. framework was developed for cancer patients [25], the variability in PCC domains across frameworks underscores that some PCC elements may be common to all patients, while others may be unique to specific conditions. This is consistent with the fact that PCC is meant to accommodate individual needs and preferences [10], which in part must be influenced by conditions or health care issues, and in part by individual characteristics. It stands to reason then that at least some aspects of PCC may be specific to women, although that was not evident in the included studies because there were no differences in PCC domains between studies comprised primarily of women [31,34-36] and other studies. Experts agree that there may not be a global definition of PCC [37]. However, our findings underscore the paucity of research on PCCW.

Strengths of this study include the use of rigorous methods [20] including a comprehensive search of multiple databases, independent screening and data extraction, compliance with standards for the reporting of review [21] and for searching of electronic databases [22], and use of a PCC framework upon which to map PCC elements from included studies [25]. Several factors may limit the interpretation and application of the findings. Despite having conducted a comprehensive search of multiple databases we may not have identified all relevant studies, in part because our search was restricted to English-language studies and studies that used the label of patient- or person-centred (or centered) care. We did not search the grey literature given the methodological challenges that have been identified by others [23, 24]; as a result, important information may have been missed. Few studies were eligible and none included solely women, so the findings may not truly represent the views of women about PCC. Risk of bias of included studies was not assessed as this is not customary for a scoping review [20]. Although scoping reviews often include consultation with stakeholders to interpret the findings, this step was not done because studies were few and provided sparse details [20]. Our analysis relied on the McCormack et al. PCC framework [25], which may not be a universally recognized or accepted framework. Still, as a comprehensive PCC framework, it served as a basis from which to assess whether and how PCCW has been studied, evaluated or improved.

The purpose of this study was to identify and compare existing PCCW frameworks. Strikingly, despite research demonstrating disparities in care among women [1-6], and global advocacy for research to improve quality of care for women [7-9], no research has conceptualized PCCW. Hence, there is little guidance on what constitutes PCCW or how to evaluate and improve PCCW. Given the aging and ethnic diversity of the female population, rise in labour force participation, shift to marriage and childbearing later in life, increase in single parent households largely headed by women, women's simultaneous roles as paid workers and caregivers, and gaps in earnings for women compared with men, the socioeconomic implications of poor health care for women are profound [38]. Given these socio-economic implications, consideration of PCCW is urgently needed. To better address PCCW, and in so doing alleviate or mitigate the socio-economic factors that contribute to gendered inequities in health care quality, advocates in Canada and the United States have issued recommendations for health care reform that include a focus on women's health; comprehensive, integrated programs and services meeting women's unique needs across the lifespan; better provider training about women's unique health needs and the differential effects of particular problems; vigorous public health leadership to shape the women's health agenda, recognizing the social and economic context of their lives; consideration of gender and health in all government policies; developing and implementing guidelines that include specific evidence-based gender elements; and sharing information with women directly $[38,39]$.

This review revealed several pressing areas where future research is needed. Primary research is needed to explore the elements of PCC valued by women including across different conditions. More needs to be understood about the challenges faced by women and health care professionals in achieving PCC. Finally, research is needed to examine whether and how policies, guidelines and interventions could better promote and support PCCW so that more women receive it. In addition to primary research, much could be learned from published investigations of women's health care preferences and experiences in various contexts. For example, research has explored patient-centred outcomes desired by women exposed to sexual trauma or intimate partner violence [40], and what is considered by women to be patient-centred maternity care [41]. 


\section{Conclusions}

Despite international calls for strategies to reduce gendered disparities in health care delivery and outcomes, this scoping review identified no studies that employed or developed a PCCW framework, and no studies that involved solely women in exploring how to achieve PCCW. Thus primary research is needed to generate knowledge about PCCW models, processes, facilitators, challenges, interventions and impacts.

\section{Supplementary information}

Supplementary information accompanies this paper at https://doi.org/10. 1186/s12905-019-0852-9

Additional file 1. MEDLINE search strategy.

\section{Abbreviations}

PCC: Patient-centered care; PCCW: Patient-centered care for women; PICO: Population, Intervention, Comparisons, Outcomes; PRISMA: Preferred Reporting Items for Systematic Reviews and Meta-Analysis

\section{Acknowledgements}

We thank Kainat Bashir and Helen Liu for assistance with data acquisition and analysis.

\section{Authors' contributions}

ARG conceived the study, acquired funding, planned and led the study; acquired, analyzed and interpreted data; drafted and finalized the manuscript, and is accountable for the work. BBN helped to oversee other staff, collect, analyze and interpret data, draft the manuscript, and is accountable for the work. SD, SLG, CG, DES, and FCW helped to conceive and plan the study, interpret data, draft and revise the manuscript, and are accountable for the work. All authors read and approved the final version of the manuscript.

\section{Funding}

This study was funded by the Ontario Ministry of Health and Long Term Care Health Services Research Fund. The funder took no part in the design of the study; collection, analysis or interpretation of data; or in writing the manuscript.

\section{Availability of data and materials}

The dataset(s) supporting the conclusions of this article is (are) included within the article (and its additional file(s).

\section{Ethics approval and consent to participate}

Not applicable.

\section{Consent for publication}

Not applicable.

\section{Competing interests}

The authors declare that they have no competing interests.

\section{Author details}

'Toronto General Hospital Research Institute, University Health Network, 200 Elizabeth Street, 13 EN-228, Toronto, ON M5G2C4, Canada. ${ }^{2}$ Toronto General Hospital Research Institute, University Health Network, Toronto, Canada. ${ }^{3}$ Women's College Hospital, Toronto, Canada. ${ }^{4}$ York University and University Health Network, Toronto, Canada. ${ }^{5}$ Society of Obstetricians and Gynaecologists of Canada, Ottawa, Canada. ${ }^{6}$ Sunnybrook Health Sciences Centre, Toronto, Ontario, Canada.
Received: 28 January 2019 Accepted: 15 November 2019

Published online: 10 December 2019

\section{References}

1. White AA, Stubblefield-Tave B. Some advice for physicians and other clinicians treating minorities, women, and other patients at risk of receiving health care disparities. J Racial Ethn Health Disparities. 2017;4:472-9.

2. Colella TJ, Gravely S, Marzolini S, Grace SL, Francis JA, Oh P, et al. Sex bias in referral of women to outpatient cardiac rehabilitation? A meta-analysis Eur J Prev Cardiol. 2015;22:423-41.

3. Bennett AL, Lavie CJ, Grace SL. Cardiac rehabilitation following acute coronary syndrome in women. Curr Treat Options Cardiovasc Med. 2017;19:57.

4. Araújo C, Laszczyńska O, Viana M, Dias P, Maciel MJ, Moreira I, et al Quality of Care and 30-day Mortality of Women and Men With Acute Myocardial Infarction. Rev Esp Cardiol (Engl Ed). 2018; doi: https://doi.org/10.1016/j.rec. 2018.05.012

5. Carter A, Borrero S, Wessel C, Washington DL, Bean-Mayberry B, Corbelli J. Racial and ethnic health care disparities among women in veterans affairs healthcare system: a systematic review. Womens Health Issues. 2016;46:401-9.

6. Joulaei H, Maharlouei N, Lankarani KB, Razzaghi A, Akbari M. Narrative review of women's health in Iran: challenges and successes. Int J Equity Health. 2016:15:25

7. World Health Organization. Women and Health. Today's Evidence, Tomorrow's Agenda. Geneva: WHO Press; 2009.

8. Langer A, Meleis A, Knaul FM, Atun R, Aran M, Arreola-Ornelas H, et al Women and health: the key for sustainable development. Lancet. 2015;386: $1165-210$

9. United Nations. (2018). Gender equality in the 2030 agenda for sustainable development

10. Epstein RM, Street RL. The values and value of patient-centered care. Ann Fam Med. 2011:9:100-3.

11. Rathert C, Wyrwich MD, Boren SA. Patient-centered care and outcomes: a systematic review of the literature Med Care Res Rev 2013:70:351-79.

12. Doyle $C$, Lennox L, Bell D. A systematic review of evidence on the links between patient experience and clinical safety and effectiveness. BMJ Open. 2012;3:e001570

13. Stewart M, Ryan BL, Bodea C. Is patient-centred care associated with lower diagnostic costs? Healthcare Policy. 2011;6:27-31.

14. Constand MK, MacDermid JC, Dal Bello-Haas V, Law M. Scoping review of patient-centered care approaches in healthcare. BMC Health Serv Res. 2014; $14: 271$.

15. Hudon C, Fortin M, Haggerty $J$, Lambert M, Poitras ME. Measuring patients perceptions of patient-centered care: a systematic review of tools for family medicine. Ann Fam Med. 2011:9:155-64.

16. Fowler FJ, Gerstein BS, Barry MJ. How patient centered are medical decisions? Results of a national survey. JAMA Intern Med. 2013:173:1215-21.

17. Bertakis KD, Azari R. Determinants and outcomes of patient-centered care. Patient Educ Couns. 2011:85:46-52.

18. Hasnain M, Connell KJ, Menon U, Tranmer PA. Patient-centered care for Muslim women: provider and patient perspectives. J Women's Health. 2011; 20:73-83.

19. Davis K, Drey N, Gould D. What are scoping studies? A review of the nursing literature. Int J Nurs Stud. 2009:46:1386-400.

20. Arksey H, O'Malley L. Scoping studies: towards a methodological framework Int J Soc Res Methodol. 2005:8:19-32.

21. Moher D, Liberati A, Tetzlaff J, Altman DG. The PRISMA group. Preferred Reporting Items for Systematic Reviews and MetaAnalyses: the PRISMA statement BMJ. 2009;339:b2535

22. McGowan J, Sampson M, Salzwedel DM, Cogo E, Foerster V, Lefebvre C. PRESS peer review of electronic search strategies: 2015 guideline statement. J Clin Epidemiol. 2016 Jul 1;75:40-6.

23. Benzies KM, Premji S, Hayden KA, Serrett K. State-of-the-evidence reviews: advantages and challenges of including grey literature. Worldviews EvidBased Nurs. 2006:3:55-61.

24. Adams J, Hillier-Brown FC, Moore HJ, Lake AA, Araujo-Soares V, White M, et al. Searching and synthesising 'grey literature' and 'grey information' in public health: critical reflections on three case studies. Syst Rev. 2016;5:164

25. McCormack LA, Treiman K, Rupert D, Williams-Piehota P, Nadler E, Arora NK, et al. Measuring patient-centered communication in cancer care: a literature 
review and the development of a systematic approach. Soc Sci Med. 2011; 72:1085-95.

26. Cheraghi MA, Esmaeili M, Salsali M. Seeking humanizing care in patientcentered care process: A grounded theory study. Holis Nurs Pract. 2017;31: 359-68.

27. Cuevas AG, O'Brien K, Saha S. What is the key to culturally competent care: reducing bias or cultural tailoring? Psychol Health. 2017;32:493-507.

28. Adamson E, Pow J, Houston F, Redpath P. Exploring the experiences of patients attending day hospitals in the rural Scotland: capturing the patient's voice. J Clin Nurs. 2017;19-20:3044-55.

29. Gill M, Bagshaw SM, McKenzie E, Oxland P, Oswell D, Boulton D, et al. Patient and family member-led research in the intensive care unit: a novel approach to patient-centered research. PLoS One. 2016;11:e0160947.

30. Doubova SV, Guanais FC, Pérez-Cuevas R, Canning D, Macinko J, Reich MR. Attributes of patient-centered primary care associated with the public perception of good healthcare quality in Brazil, Colombia, Mexico and El Salvador. Health Policy Plan. 2016;31:834-43.

31. Raja S, Hasnain M, Vadakumchery T, Hamad J, Shah R, Hoersch M. Identifying elements of patient-centered care in underserved populations: a qualitative study of patient perspectives. PloS one. 2015;10):e0126708.

32. van Leijen-Zeelenberg JE, Huismans GW, Bisschop JA, Brunings JW, van Raak AJ, Vrijhoef $\mathrm{HJ}$, et al. Experiences and preferences of patients visiting an otolaryngology outpatient clinic: a qualitative study. Health Expect. 2016;19: 275-87. .

33. Papp R, Borbas I, Dobos E, Bredehorst M, Jaruseviciene L, Vehko T, et al. Perceptions of quality in primary health care: perspectives of patients and professionals based on focus group discussions. BMC Fam Pract. 2014;15:128.

34. Marshall A, Kitson A, Zeitz K. Patients' views of patient-centred care: a phenomenological case study in one surgical unit. J Adv Nurs. 2012;68: 2664-73.

35. Bann CM, Sirois FM, Walsh EG. Provider support in complementary and alternative medicine: exploring the role of patient empowerment. J Altern Complement Med. 2010;16:745-52.

36. Davis $\mathrm{S}$, Byers $\mathrm{S}$, Walsh F. Measuring person-centred care in a sub-acute health care setting. Aust Health Rev. 2008;32:496-504.

37. Stewart M. Towards a global definition of patient centred care. BMJ. 2001; 322:444-5.

38. Strobino DM, Grason H, Minkovitz C. Charting a course for the future of women's health in the United States: concepts, findings and recommendations. Soc Sci Med. 2002;54:839-48.

39. Framework O W's H. Toronto: effecting change for Women's health in Ontario; 2011

40. Grillo AR, Danitz SB, Dichter ME, Driscoll MA, Gerber MR, Hamilton AB, et al. Strides toward recovery from intimate partner violence: elucidating patientcentered outcomes to optimize brief counseling intervention for women. J Interpers Violence. 2019. https://doi.org/10.1177/0886260519840408 [Epub ahead of print].

41. Petit-Steeghs V, Lips SR, Schuitmaker-Warnaar TJ, Broerse JEW. Clientcentred maternity care from women's perspectives: need for responsiveness. Midwifery. 2019;74:76-83.

\section{Publisher's Note}

Springer Nature remains neutral with regard to jurisdictional claims in published maps and institutional affiliations.

\section{Ready to submit your research? Choose BMC and benefit from:}

- fast, convenient online submission

- thorough peer review by experienced researchers in your field

- rapid publication on acceptance

- support for research data, including large and complex data types

- gold Open Access which fosters wider collaboration and increased citations

- maximum visibility for your research: over $100 \mathrm{M}$ website views per year

At $\mathrm{BMC}$, research is always in progress.

Learn more biomedcentral.com/submissions 